\title{
Maya Phytomedicine in Guatemala - Can Cooperative Research Change Ethnopharmacological Paradigms?
}

First \& corresponding author: Martin Hitziger, ETH Zürich, TdLab, Universitätsstrasse 22, CHN, 8092 Zurich, Switzerland, martin.hitziger@usys.ethz.ch

Michael Heinrich Research Cluster Biodiversity and Medicines/Centre for Pharmacognosy and Phytotherapy, UCL School of Pharmacy, London, WC1N 1AX UK. E-mail: m.heinrich@ucl.ac.uk

Peter Edwards, Director, Singapore-ETH Centre, 1 CREATE Way, \#06-01 CREATE Tower, Singapore 138602, peter.edwards@env.ethz.ch

Elfriede Pöll, Universidad del Valle de Guatemala, Instituto de Investigaciones, Herbario UVAL, 18 Avenida 11-95, Zona 15,V.H. III, Guatemala Guatemala. C.A., epoell@uvg.edu.gt

Marissa Lopez, Universidad del Valle de Guatemala, 18 Avenida 11-95, Zona 15,V.H. III, Guatemala Guatemala. C.A., lop.marissa@gmail.com

Pius Krütli, ETH Zurich, TdLab, Universitätsstrasse 22, CHN, 8092 Zurich, Switzerland, pius.kruetli@usys.ethz.ch 


\section{Abstract}

Ethnopharmacological relevance: This paper presents one of the first largescale collaborative research projects in ethnopharmacology, to bring together indigenous stakeholders and scientists both in project design and execution. This approach has often been recommended but rarely put into practice. The study was carried out in two key indigenous areas of Guatemala, for which very little ethnopharmacological fieldwork has been published.

Aim of the study: To document and characterize the ethno-pharmacopoeias of the Kaqchikel (highlands) and Q'eqchi' (lowlands) Maya in a transdisciplinary collaboration with the two groups Councils of Elders.

Materials and Methods: The project is embedded in a larger collaboration with five Councils of Elders representing important indigenous groups in Guatemala, two of which participated in this study. These suggested healing experts reputed for their phytotherapeutic knowledge and skills. Ethnobotanical fieldwork was carried out over 20 months, accompanied by a joint steering process and validation workshops. The field data were complemented by literature research and were aggregated using a modified version of the International Classification of Diseases (ICD-10) and Trotter \& Logan's consensus index.

Results: Similar numbers of species were collected in the two areas, with a combined total of 530 species. This total does not represent all of the species used for medicinal purposes. Remedies for the digestive system, the central nervous system \& behavioral syndromes, and general tissue problems \& infections were most frequent in both areas. Furthermore, remedies for the blood, immune \& endocrine system are frequent in the Kaqchikel area, and remedies for the reproductive system are frequent in the Q'eqchi' area. Consensus factors are however low. The Kaqchikel, in contrast to the Q'eqchi', report more remedies for non-communicable illnesses. They also rely heavily on introduced species.

Discussion \& Conclusions: The transdisciplinary research design facilitated scientifically rigorous and societally relevant large-scale fieldwork, which is clearly beneficial to indigenous collaborators. It provided access and built trust as prerequisites for assembling the largest comparative ethnopharmacological collection, vastly extending knowledge on Maya phytotherapy. The collection represents knowledge of the two groups' most reputed herbalists and is a representative selection of the Guatemalan medicinal flora.

ICD-10 proved useful for making broad comparisons between the groups, but more refined approaches would be necessary for other research objectives. Knowledge in the two areas is highly diverse and seems fragmented. New approaches are required to assess how coherent Maya phytotherapy is. The documented 'traditional' ethno-pharmacopoeias demonstrate dynamic change and acculturation, reflecting the two linguistic groups' sociocultural history and context. This highlights the adaptive potential of phyto-therapeutic knowledge and calls the equation of local indigenous pharmacopoeias with 'traditional' medicine into question. We suggest using the term 'local' pharmacopoeias, and reserving the term 'traditional' for the study of indigenous pharmacopoeias with a clear delineation of ancient knowledge. 


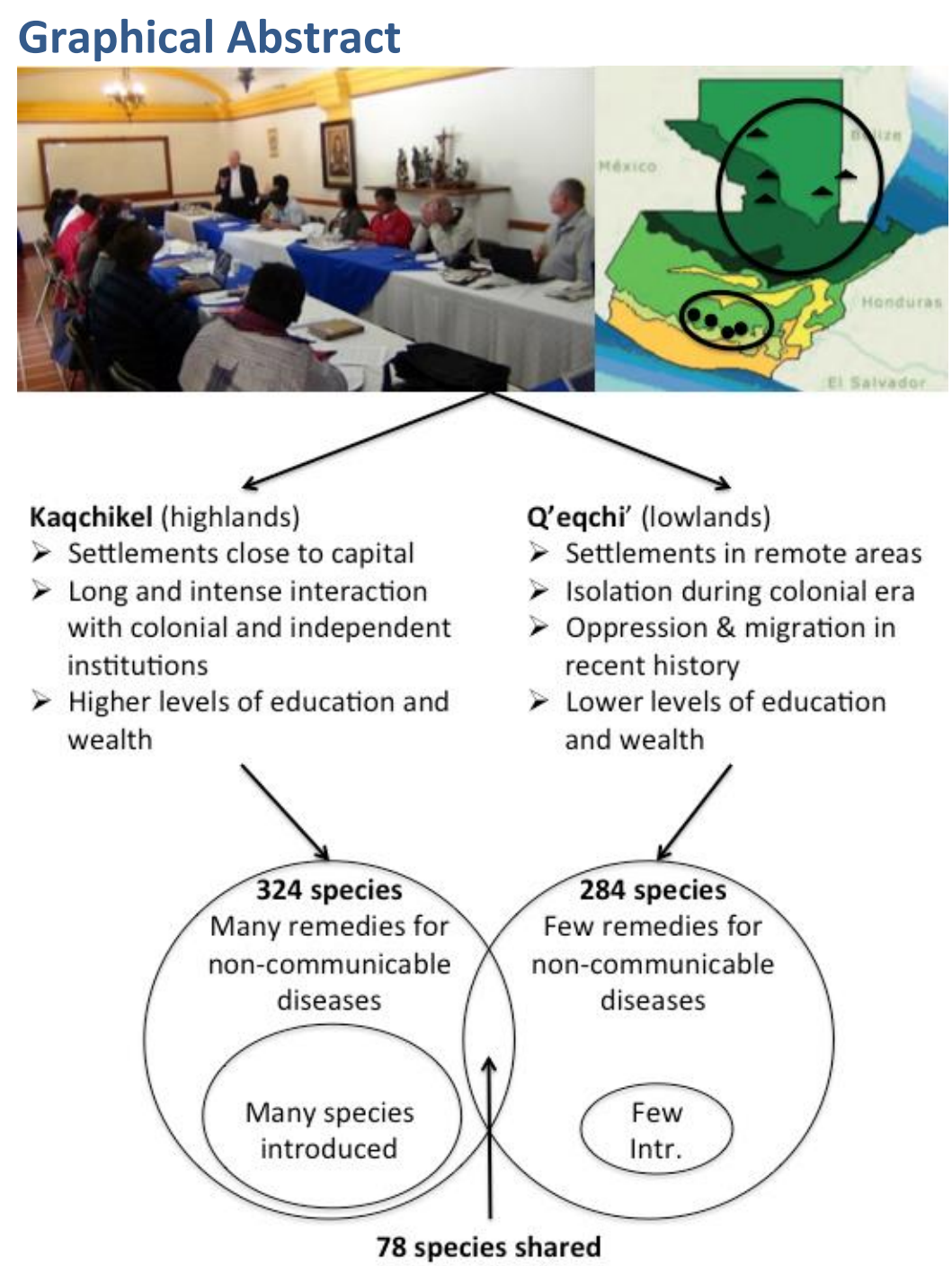

\section{Keywords}

Guatemala, Traditional Medicine, Culture Change, Comparative Research, Participative Research, Transdisciplinary Research

\section{Introduction}

Ever since the Spanish conquest of Central America, local phytotherapy has captured the attention of western and, more rarely, native scholars. Individual investigations and systematic efforts of various Mexican institutions in all parts of México resulted in rich anthropological descriptions and inventories of medicinal flora containing several thousand species (Bye et al. 1995). Traditional medicine in the post-classic Mayan states in Guatemala received less attention, partly, because investigations were hampered by weak national institutions and a civil war. International efforts have focused upon pharmacological tests of selected species (Gridling et al. 2009, Madlener et al. 2009), local pharmacopoeias (Kufer et al. 2005, Pöll et al. 1995), or treatments of particular diseases or systems (Cáceres et al. 1995, Michel et al. 2007). A host of grey or unpublished literature of diverse quality also exists. However, only two 
systematic editions of Guatemalan pharmacopoeia have been compiled (Cáceres 2009, Roque 1941), listing about 100 and 40 medicinal plants, respectively. Of these, many are naturalized, cultivated or commercially available species likely to be derived from Mestizo concepts and knowledge. In contrast, systematic knowledge on medicinal flora and Mayan phytotherapy in Guatemala remains largely inaccessible.

'Transdisciplinarity' (TD) has been suggested as one avenue for strengthening ethnopharmacology. Very often TD has been defined as methodology that integrates the perspectives, objectives and tools of diverse disciplines (Etkin and Elisabetsky 2005). It is thus conceptualized as a research collaboration in which knowledge production and decision making power remain unilaterally within academia. Based on the perspectives of collaborative research (Arnstein 1969, Krütli et al. 2010, Stauffacher et al. 2008) this has to be considered information and consultation based approaches. In contrast, collaboration and empowerment aim at facilitating mutual learning and knowledge co-production by integrating non-academic stakeholders into the research process (Pohl et al. 2010). Such participatory collaborations involving local and indigenous institutions in all phases of research have been promoted to respect the Nagoya Protocol on Access and Benefit Sharing (Convention on Biological Diversity 2015), to improve comprehension of cultural constructions and social transactions (Etkin and Elisabetsky 2005) and to contribute to the survival of indigenous cultures (Martin et al. 2010). The International Cooperative Biodiversity Project project in Mexico was one pioneering example (Berlin and Berlin 2004). At smaller scale, similar concepts were implemented in Belize (Balick and Arvigo 2015, Pesek et al. 2010). While previous efforts certainly worked towards such goals, there has, however, been no attempt to integrate cooperative approaches systematically from study design to completion, and most remain conducted in a conventional fashion.

The TD approach taken in this study aimed to strengthen collaboration by:

1) Studying problems that are formulated and structured jointly or in close contact with (in this case indigenous) practitioners and those concerned.

2) Teams formed with disciplinary experts, but also with practitioners and other stakeholders.

3) Conducting research as a collaborative effort, involving close contact between researchers and practitioners.

4) Disseminating results among the wider public. (Häberli and Grossenbacher-Mansuy 1998 in Pohl and Hirsch-Hadorn 2007).

We focused at the following research question: What characterizes the regional ethno-pharmacopoeias of two linguistic Maya groups in Guatemala? The results are discussed with emphasis on three aspects:

1) The TD design in the light of the representativeness, completeness and comprehensiveness of the gathered information,

2) The use of the International Classification of Diseases (ICD-10) in intercultural comparative research, and

3) The two region's ethno-pharmacopoeias in the light of their divergent societal contexts and sociocultural histories. 


\section{Background}

\subsection{The study area and its sociocultural history}

Guatemala is a medium-sized country in the outer tropics $\left(109000 \mathrm{~km}^{2}\right)$ with a population of some 15 million people, located on the Central American isthmus (CIA 2015, Figure 1a). It comprises two major geological zones. As part of the Pacific ring of fire, its western and southwestern stretches along the Pacific coast are formed by volcanic highlands ("Altiplano") at altitudes between 1500 and $3000 \mathrm{~m}$, with the highest peaks reaching beyond $4000 \mathrm{~m}$. The eastern and northeastern stretches are wide, plain to hilly limestone lowlands ("Petén"), mostly between 200 and $700 \mathrm{~m}$. The transitional zone towards the highlands in the west ("Verapaces") is also built on limestone. The region has one of the most diverse floras in the world (Myers et al. 2000), as a consequence its tropical location, its large altitudinal range, diverse habitats and geological conditions, and its location between the holarctis and the neotropis. As shown in Figure 1b, this flora has been classified into seven overarching biomes.
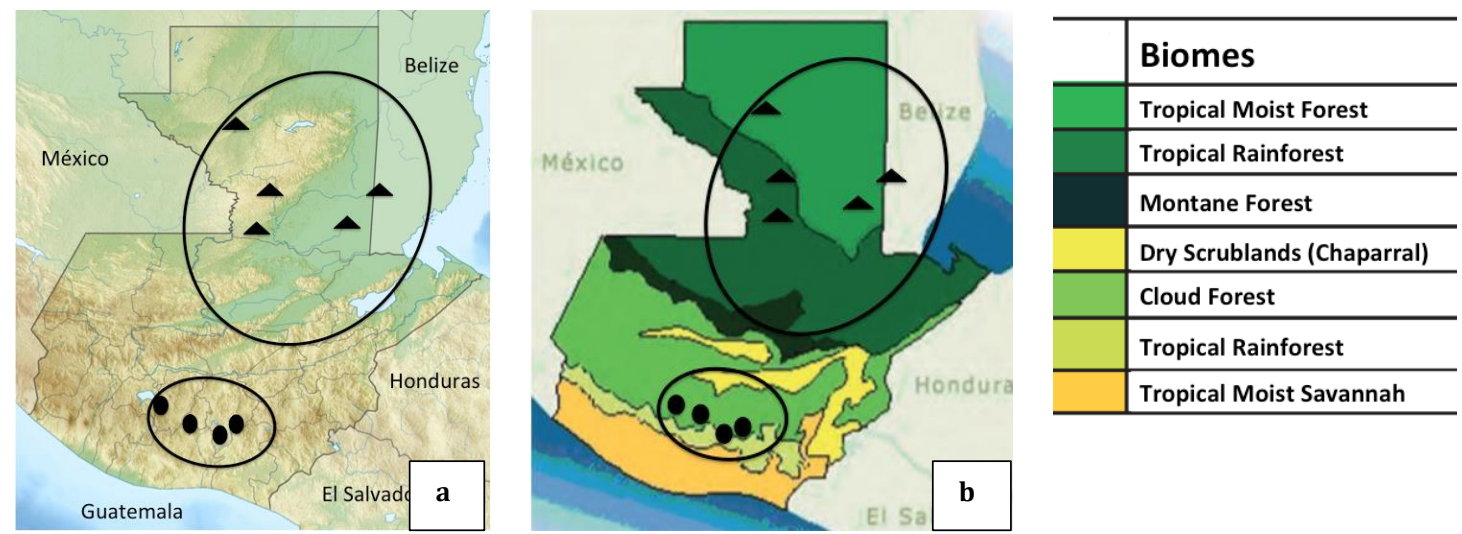

Fig. 1a: Physio-geographic map of Guatemala. Highlands in the west and southwest alongside the Pacific lowlands in the north and north-east towards the Carribean. 1b: Bio-geographic zonation of major biomes according to (Castañeda 2008, CONAP 1999, Villar-Anleu 1998). Locations of healer's villages approximated with dots (Kaqchikel) and triangles (Q'eqchi'). Linguistic areas approximated with circles.

Culturally, Guatemala is part of Mesoamerica (Kirchhoff 1943). In the lowlands, Mayan cultures created flourishing city-states until the end of the so-called classic period (ca. 1000 A.D.), after which there are only few archaeological traces of populations. In the highlands, smaller political entities existed until the Spanish conquest in 1524 (Carcache 1994). More than 20 different linguistic groups still exist today, forming $40 \%$ of the population (Instituto Nacional de Estadística 2014). Two major groups were selected for the study: the Kaqchikel in the highlands (451'000 speakers) and the Q'eqchi' in the Verapaces and Petén (800'000 speakers, Ethnologue 2015). This approach allowed us to compare linguistic groups and also to cover different floristic zones.

The Kaqchikeles were among the first groups in contact with the Spanish, who built their capitals next to the Kaqchikeles' ceremonial-theocratic population center. While the Kaqchikeles retained most of their lands until after Guatemalan independence, they were required to provide labor force to local Spanish lords, which often turned into slavery. In 1537, the crown introduced the "new laws of the Indies", providing some minimal humanitarian protection (Aguilar 1994). It also established so-called "reductions", forcing scattered hamlet populations to resettle in centralized villages where they could be better controlled, more easily 
converted to Christianity, and made to work on public projects (Carcache 1994). Since exchange between reductions was restricted, previously diffuse linguistic differences developed into local dialects, while Spanish gained prominence around the capital (Richards and Richards 1994).

In the region occupied by the Q'eqchi', the Spanish conquest took a different course. After several failed military expeditions, Dominican monks were successful in converting the population peacefully, and the former war zone was thus transformed into the Dominican Mission of the True Peace named "Verapaces". This put the Q'eqchi' directly under the control of the crown, and prevented any Spaniards from entering the region. The Dominicans defended this mission to the point of sacking Spanish settlers by means of Spanish military force (Saint-Lu 1994). Therefore, the Q'eqchi' were less rigorously separated into reductions, did not develop local dialects, and retained an identity towards their linguistic group in general (Herrera 1997). Around 1700 AD, the Spanish capital in the Kaqchikel area thus had a population of 30'000 non-indigenous people, whereas in all the Verapaces, accounts register only 20 non-indigenous families (Lutz 1994). The indigenous populations of Petén were only defeated in 1697 (Didier 1994), after which the lowlands fell almost unoccupied (Jones 1940).

With the liberal governments of independent Guatemala in the 19th century, the reductions system was abolished, but the indigenous population was also stripped of the minimal protection under Spanish rule (McCreery 1995a). Immigrants entered rural areas, including the Verapaces, where they acquired large plantations, deprived the population of their land and forced them into debt peonage (McCreery 1995b). Additionally, population growth was significant, and each generation of smallholders was forced to further subdivide the remaining lands or to migrate. By 1960, policies were approved to settle and develop the lowlands. A first road connection was established in 1965 (Riera 1997). By 1981, Petén's population had grown more than tenfold (Schwartz 1990), 85\% of it indigenous (Adams 1997). During the Guatemalan armed conflict in the 70's and 80's, the military targeted indigenous villages and their leaders, with the Verapaces and Petén being at the heart of the conflict (Kahn 2006). A peace treaty was signed as recently as in 1996 (Adams 1997).

Therefore, the Q'eqchi', who had emerged from the colonial period with less experience of outside repression, migrated to occupy much of Petén and parts of Belize, vastly extending their historical core area in the Verapaces. The Kaqchikeles had been in contact with colonial and national society for much longer, remained in their original areas, and escaped some of the worst abuses of recent decades.

\subsection{Institutional platform \& transdisciplinary (TD) project design}

In 2010, a Memorandum of Understanding (MoU) was established between the ETH Zurich, the Del Valle University of Guatemala and the Councils of Elders of 5 major linguistic Maya groups. First contact with the Councils of Elders as officially recognized representatives of their linguistic groups was made through Cirilo Perez Oxlaj, the indigenous itinerant ambassador of Guatemala (20082012). It was agreed to document Maya medical culture using a TD approach. For this, 13 traditional healers of various specializations were interviewed in each linguistic area. They were selected by the Councils (i.e. from an emic viewpoint) for their high reputation and experience. This project has been thoroughly 
described elsewhere (Berger-Gonzalez 2015, Berger-Gonzalez et al. 2016). During this process, the lack of information on Maya phytotherapy in Guatemala became apparent. Thus the Councils suggested to document traditional phytotherapeutic knowledge, to strengthen the identity of Mayan medicine, to build societal awareness, and to preserve the knowledge for future generations.

Negotiations commenced in September 2012. In an extension of the MoU, Del Valle University agreed to voucher the collection under permissions granted to its Herbarium, to identify botanical specimen and to train staff in fieldwork methods. The Councils agreed to scientifically publish results. They also agreed to facilitate contact with healers, to accompany fieldwork researchers and translate where required, and to select one person per group to be trained as fieldwork assistant. In turn, systematic activities would engage the Elders and healers to discuss and steer the field research, to create opportunities for exchange and clarification of ambiguities, to contribute to understanding and appreciation of potential benefits, and thus to facilitate learning in the process of conducting the research. As part of the overall project, a chapter on Mayan phytotherapy would be contributed to a book on Mayan medicine, written from an emic perspective, in an accessible style and in local languages, and validated by a Maya editorial board. This book "Raxnaq'il Nuk'aslemal: Medicina Maya en Guatemala" (Consejo Mayor de Médicos Maya por Nacimiento) was presented to project partners and representatives from politics and media in March 2016 in the National Presidential Palace in Guatemala City.

The TD process thus enabled the field research by empowering local collaborators: (1) The councils were from the outset involved in framing the research, (2) responsibility was shared between a coalition of local indigenous representatives, national botanical experts and international specialists in collaborative processes, (3) the botanical sampling was accompanied by iterative interactions that facilitated mutual learning on several levels, (4) the research was part of a wider effort to strengthen Mayan medical identity by collaboratively producing and disseminating systematic information, and providing opportunities for mutual understanding and networking with other sectors of Guatemalan society.

\section{Methods}

\subsection{Informant selection}

The informant selection was a two-step process, designed to access "emically eminent phyto-therapeutic specialists". In a first step, ETH Zurich selected the Kaqchikel (highlands) and the Q'eqchi' (lowlands) groups, to represent important floristic zones, due to preliminary data on relevance of phytotherapy in their respective medical traditions, and for practical reasons such as reliability, internal organization, legitimacy and rapport with healers. In a second step, their Councils chose healers with locally reputed specialist knowledge in phytotherapy. The strategy thus took advantage of local knowledge and perceptions of healer's skill, experience and reputation. It furthermore built on existing networks and trust, which were extended and deepened by facilitating interactions throughout the research period. 


\subsection{Field research \& botanical documentation}

Fieldwork staff from Maya councils and ETH were jointly trained at Del Valle University in spring 2013. Initial workshops between Mayan healers, Council members and ETH staff offered an opportunity for the collaborators to get to know each other and explore methods. The main sampling took place between September 2013 and May 2015. In the highlands, research was conducted in Spanish in which all healers are fluent. In the lowlands, research was conducted in Q'eqchi', which required a council member to be present at all times to translate and also to increase trust. First visits to each healer were extensive and were always made by the first author. Several days were spent in free-listing medicinal species, recording local names, and in documenting uses, preparations, recipes, and other information pertinent to the healer. To obtain the fullest coverage possible, species were collected at different times of year and in different places. Especially in the lowlands, collections took place up to $100 \mathrm{~km}$ from healer's homes. This involved repeated follow-up visits, some of which were made by the trained assistants. Regular meetings with Council members were held throughout the fieldwork, which were important for securing feedback and resolving differences and misunderstandings.

Samples of all encountered medical species were collected, amending the freelisted information where required. Sampling locations and altitudes were recorded with GPS. Vouchers were delivered to the Herbarium of Del Valle University for identification, with some families cross-checked by experts in other herbaria. The main collection is stored at Del Valle University, while a duplicate collection is to be exported to ETH Zurich (pending due to the concerned institutions not having developed procedures for granting export permissions under the Nagoya protocol). All botanical names were validated in The Plant List (The Plant List 2013). Due to financial and time constraints, it was decided early on not to collect commonly known cultivated or marketed species which are shared widely among Guatemalan Indigenous and Mestizo groups.

Fieldwork ended in April 2015 with validation workshops in both groups, attended by council members and healers. These meetings were an opportunity to check local names and uses of species with healers, to clarify ambiguities, and to establish correspondences between collected species and uncollected use reports of other healers. In addition, the workshops were designed to report findings back to the community representatives in a culturally adapted form.

\subsection{Database research \& data analysis}

Every record of a species being used by a healer was counted as use report (UR). Some species, mostly ubiquitous introduced or marketed species in cut, ground or processed form were not collected. To reduce the bias of systematically excluding important components of Mayan phytotherapy, in instances in which the UR referred to clearly defined common and widely recognized species like fenugreek (Trigonella foenum-graecum L.) or garlic (Allium sativum L.), the Latin binomials were inferred from general literature and validated with The Plant List (The Plant List 2013). As suggested in terms of good ethnopharmacological practice (Heinrich et al. 2009), the supplementary material (Table 6) specifies whether a species was identified by voucher specimen or literature research. Unidentified species were not included in the further analysis. 
Representativeness of the collection was determined by the sampling design. In Section 4.1, botanical representativeness of the sample for the Guatemalan medicinal flora is analyzed in terms of covered altitudes and biomes. In Section 4.2, cultural representativeness for the phytotherapeutic traditions is analyzed in terms of decisions made in healer selection. To analyze for completeness and comprehensiveness of the database, Section 4.3. presents UR's and their repetitions, and numbers of identified species are compared with the national Vademecum of Medicinal Plants (Cáceres 2009).

In Section 4.4, a classification system of the recorded uses is presented, derived from the World Health Organization's International Statistical Classification of Diseases and Related Health Problems (ICD-10) (World Health Organization 2015), modified in the light of emic Maya conceptualizations and fieldwork constraints. The frequency of UR's in the different classes is presented in Section 4.5. In Section 4.6, the data is aggregated with Factor of Informant Consensus index, FIC (Heinrich et al. 1998, Trotter and Logan 1986), to analyze for coherence of uses (Formula 1). The index derives from the difference of numbers of UR's ( $\left.\mathrm{N}_{U R}\right)$ and referred taxa $\left(\mathrm{N}_{\mathrm{t}}\right)$, normalized by dividing by $\mathrm{N}_{U R}$. It therefore specifies consensus or coherence in uses of a given taxa in the range of 0 (NuR $=$ $\left.\mathrm{N}_{\mathrm{t}}\right)$ and $1\left(\mathrm{~N}_{\mathrm{t}}=1\right)$.

$$
F_{i C}=\frac{N_{U R}-N_{t}}{N_{U R}-1}
$$

Formula 1

This analysis is on the genus level since it has been argued that many wellknown medicinal plants are actually found in 'plant complexes', i.e. different species with similar functions, appearances, often related phylogeny and vernacular names (Bye and Linares 2015, Linares and Bye 1987). Preliminary analyses provided indications of this being the case in Guatemala (Hitziger et al. 2016).

The phytogeographic origins of the species were researched in the National Vademecum of Guatemalan Medicinal Plants (Cáceres 2009) and the Flora Mesoamericana (Missouri Botanical Garden 2015). These results are presented in Section 4.7.

\section{Results \& discussion}

\subsection{Database representativeness for the indigenous groups}

The Kaqchikel Council suggested four healers to work with and the Q'eqchi' council suggested six. Since two of the latter were brothers working as a team and sharing most of their knowledge, they were treated as a single source of information. Table 1 presents information on the healers' sociocultural background and education. In both groups, they had roughly the same age and with a strong bias towards males. All healers specialized in phytotherapy, almost all do also practice spiritual healing. The one female selected by the Kaqchikel council additionally works as a midwife. On all other variables there were differences. Kaqchikel healers have been, in contrast to Q'eqchi' healers, permanently resident in their municipality of birth, have received formal education, speak Spanish fluently and enjoy higher standards of living. 


\begin{tabular}{|c|c|c|c|c|c|c|c|c|c|}
\hline & Sex & Age & History of Migration & Western Schooling & Maya Specialization & Spanish & E. & T. & F. \\
\hline \multirow{4}{*}{ 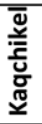 } & $\mathrm{M}$ & 56 & Living in municipality of birth & Primary school & Herbalist & high & + & + & + \\
\hline & $M$ & 47 & Living in municipality of birth & Apprenticeship (nurse, dentist) & Herbalist, Spiritual Guide & high & + & + & + \\
\hline & M & 57 & Living in municipality of birth & University degree (soc. sc.) & Herbalist, Spiritual Guide & high & + & + & + \\
\hline & $\mathrm{F}$ & 40 & Living in municipality of birth & Apprenticeship (nurse) & Herbalist, Spiritual Guide, Midwife & high & + & + & + \\
\hline \multirow{5}{*}{$\begin{array}{l}\bar{c} \\
\bar{y} \\
\bar{d} \\
\bar{o}\end{array}$} & $M$ & 51 & Verapaz --> Petén & Almost none & Herbalist, Spiritual Guide & very low & - & + & - \\
\hline & M & 63 & Verapaz --> Petén & Almost none & Herbalist, Spiritual Guide & very low & - & + & - \\
\hline & M & 67 & Living in municipality of birth & None & Herbalist, Spiritual Guide & low & + & + & - \\
\hline & M & NA* & Petén --> Petén & None & Herbalist, Spiritual Guide & very low & - & - & - \\
\hline & M & $65 / 43$ & Petén --> Belize & Almost none / primary school & Herbalist, (Spiritual Guide) & low & - & - & - \\
\hline
\end{tabular}

Table 1: Sociocultural background of the 10 healers (2 of them brothers and treated as single source of information) participating in the research. Spanish: Spanish fluency. E: Electricity in house. T: Tap water in house. F: Flushed toilet in house. This information was received in semi-structured interviews, and by field observations.

These differences reflect the sociocultural context, as outlined in Section 2.1: the Kaqchikele's history of interaction with the nation's centers of development increased their fluency in Spanish, and is reflected in higher schooling levels and a higher standard of living. They settled into stable municipal groups ever since the establishments of the new laws of the Indies. In contrast, the Q'eqchi' were less rigorously reduced but, following clashes with large-scale coffee growers in the Verapaces in the $19^{\text {th }}$ century, were forced to migrate to the sparsely populated lands of Petén. More recently, they were severely hit by the civil war. The question of whether the healers' knowledge can be considered representative of the two groups phyto-therapeutic traditions needs to be answered in terms of how the healers were selected. It could be argued that the healers who agreed to participate were more innovative than the average, implying that 'traditionalists' were less well represented. However, the trust relations built with the Councils during this project should have minimized any bias. Furthermore, the Councils were asked to select locally eminent specialists in healing with plants, which they appear to have been done; all the chosen healers were experienced herbalists, and most of them also had a reputation as spiritual healers. Field insight further suggests that selection was done according to the agreed criteria; healers were contacted in diverse locations, surnames do not match the ones of the council members, and kinship relations between council members and healers seem to exist in only one single case. The overrepresentation of males, especially in the Q'eqchi' area, accords with the observation of few females participating as healers or priests in major ceremonial events. We conclude, therefore, that the healer selection represented two major healing specializations, and was representative of emic notions of healing reputation and knowledge in phytotherapy.

\subsection{Database representativeness for the Guatemalan medicinal flora}

Figure 1 (Section 2.1) depicts the settlement regions of the two groups and the homes of the selected healers on a physio-geographic and a bio-geographic map. Altitudes of collections ranged from 100- to $600 \mathrm{~m}$ in the Q'eqchi' area, and 1400up to $2750 \mathrm{~m}$ in the Kaqchikel area. These data show that in geo-botanical terms, the sampling covered most of Guatemala's terrestrial biomes and altitudinal ranges. In the lowlands, tropical moist forests and rainforests are covered, and in the highlands and towards higher levels of the pacific slope, tropical rainforests and cloud forests are included. The two coastlines, moist savannahs alongside the Pacific slope, as well as medium altitude montane forests in the Verapaces, and dry scrublands and the highest peaks in the highlands are left out. With the exception of Verapaces, however, these biomes occupy areas where the 
indigenous population density is very low. A final restriction was observed in the field, since a few species flowering in the treetops could not be collected. Overall however, the sampling covered a set of biomes that is representative of the Guatemalan terrestrial flora, with certain well-defined limitations.

\subsection{Database completeness \& comprehensiveness}

A total of 1403 UR's were recorded, of which 1049 UR's were identified at least to family level. 736 UR's were supported by voucher specimen from the same healer and 176 UR's were supported by voucher specimen of other healers during the validation workshops. Another 137 UR's were identified by literature research. A total of 124 families, 399 genera and 530 species were identified. Taxa representing 354 UR's could not be identified and were excluded from further analyses. The list of UR's and identifications is detailed in Table 6. Table 2 summarizes this data by linguistic group. Out of 530 identified species, around 300 were reported only a single time, and only 60 were reported more than three times.

Table 2: Overview of Use Reports (UR's) and identifications in both linguistic areas.

\begin{tabular}{l|cccc} 
& Only Q'eqchi' & Both Areas & Only Kaqchikel & Total \\
\hline Total use reports & 761 & --- & 642 & 1403 \\
\hline Species & 206 & 78 & 246 & 530 \\
Genera & 140 & 79 & 180 & 399 \\
Families & 21 & 63 & 40 & 124 \\
\hline Unknown use reports & 284 & --- & 70 & 354
\end{tabular}

The number of species identified is similar in both areas. Since there are no ethnobotanical data from earlier periods an assessment of potential knowledge loss is not possible. However, the linguistic groups' divergent migration histories or different levels of development are not reflected in different numbers of known medicinal plants. In this sense, the results of this overarching study contradict the smaller and localized investigation conducted in one migrant community in Petén by Nesheim et al. (Nesheim et al. 2006), who reported finding very little phytotherapeutic knowledge.

The number of identified species in each area is comparable to other ethnobotanical field campaigns in similar biomes, which often range between 200 and 600 species (Heinrich et al. 1998, Leonti et al. 2001). Compared to previously published knowledge in Guatemala, the present dataset is a huge step forward: The two ethno-pharmacopoeias are much larger than might be supposed from the Guatemalan Vademecum of medicinal plants (Cáceres 2009). For 57 of the 101 species referenced in that compilation, a voucher specimen was collected, for 14 others a voucher of similar plants (same genus) was collected, and 15 were identified from literature. Only 15 species are not represented at all in the database. Thus, the vast majority of the commonly known medicinal plants represented in earlier compilations were re-identified. In addition, ca. 430 species not included in this previous compilation were recorded to be used for medicinal purposes.

\subsection{Structuring medical complexity}

Table 3 shows examples of some of the most commonly reported species, and the middle columns details their uses in both groups. As these tend to be very diverse, we developed a use classification with eleven classes. Several classes 
were taken from the ICD-10 without modification, while a few were merged into superordinate classes (e.g. Blood \& Immune System" and "Endocrine, Nutritional and Metabolic Diseases"), and the "genito-urinary complaints" was split into "urinary system" and "reproductive system" due to clear distinctions of the systems in the data. The category of infectious diseases was split into "parasitic infections" and "other infections". Parasitic infections were added to the digestive system, since field data do not allow a clear distinctions to be made between gastrointestinal problems caused by parasites and those due to other causes. Other infections were added to a relatively large class of "General Tissue Problems and Infections" due to very blurry distinctions made in Mayan medicine between a large variety of inflammatory or infectious problems and neoplastic or ulceratic tissue complaints that seem crosscutting to any classification into organ systems. This field observation is confirmed by literature sources describing medical concepts in Central America (Kufer et al. 2005). The "central nervous system" category was broadened to include behavioral disorders. A class of 'spiritual-energetic uses' was added due to its emic relevance, and for all other uses in various ICD-10 categories, the remnant class "other" was introduced. Most notably, it contains all UR's referring to fever and sweating, since causes of these syndromes are manifold. The first three columns of Table 4 present the classes and common emic use concepts in each group.

Therefore, we had to modify the original categories considerably to accommodate emic conceptions of disease classifications and etiologies. Some authors would argue that it is better in these circumstances to adopt an entirely emic classification (Staub et al. 2015). However, since we are dealing with two cultural emics, this advice is of limited help. For example, in the Kaqchikel area, neoplasms are perceived to be genuinely related to ulcers, but clearly distinguished from rashes, insect bites and regular infections. In the Q'eqchi' area, the equation of cancers and ulcers is the same, but additionally related to an even larger class of tissue-related problems. The class thus had to be wide, even though in the Kaqchikel area distinctions could have been more detailed. Furthermore, since the biomedical details leading to different ICD-10 categorizations could not be verified in the field setting, some simplifying assumptions had to be made. To overcome this problem literature recommends the use of the International Classification of Primary Care (ICPC) (Staub et al. 2015). However, even in this classification, many categories would have needed to be altered in very similar ways to the ICD-10. Thus lacking perfect solutions, our system was developed as a pragmatic way of accommodating the two groups of emic conceptions in a general overview of their pharmacopoeia. Other analyses with different objectives will however require adapted classifications. 
Table 3: Example data of some of the most frequently reported species. Phytogeographic origin: Introduced (I), native (N). Habitat of collected specimen: Cultivated areas / gardens (C), open land (R), Forest (F). Source: Specimen voucher (V), literature identification of local name (L).

\begin{tabular}{|c|c|c|c|c|c|c|c|c|}
\hline & Local names & Kaqchikel area: Uses and \# of UR's & & Q'eqchi' area: Uses and \# of UR's & & Origin & Habitat & Source \\
\hline Prunus persica (L.) Batsch & Durazno & $\begin{array}{l}\text { Sacred, parasites, diarrhea, purgative, allergies, } \\
\text { bronchitis, headache, skin infections, ulcers, cancer }\end{array}$ & 4 & & 0 & I & $\mathrm{R}$ & $\mathrm{V}$ \\
\hline Senecio salignus DC. & Chilca & $\begin{array}{l}\text { Sacred, swellings, inflammations, blood circulation, } \\
\text { diuretic, uric acid, colic, bilis, analgesic, relaxant, } \\
\text { expectorant, strengthen immune system }\end{array}$ & 3 & & 0 & $\mathrm{~N}$ & $\mathrm{R}$ & $\mathrm{V}$ \\
\hline Sida acuta Burm.f. & $\begin{array}{l}\text { Escobillo, } \\
\text { Mesb'eel }\end{array}$ & Uterus, stomach problems, hair loss & 1 & $\begin{array}{l}\text { Skin: 'nacidos, bultos', gastritis, colic, } \\
\text { infertile woman or early delivery labor, }\end{array}$ & 4 & - & $\mathrm{C}, \mathrm{R}, \mathrm{F}$ & $\mathrm{V}$ \\
\hline $\begin{array}{l}\text { Siparuna thecaphora } \\
\text { (Poepp. \& Endl.) A.DC. }\end{array}$ & Chu' Che' & & 0 & $\begin{array}{l}\text { Fever, swellings, anemia, muscular cramps, } \\
\text { cough, headache, eye infections }\end{array}$ & 4 & - & $\mathrm{R}, \mathrm{F}$ & $\mathrm{V}$ \\
\hline $\begin{array}{l}\text { Stachytarpheta } \\
\text { cayennensis (Rich.) Vahl }\end{array}$ & $\begin{array}{l}\text { Cola de Armado, } \\
\text { Xye' Ajwech }\end{array}$ & & 0 & $\begin{array}{l}\text { Uterus, kidney, antidote, black magic, eye } \\
\text { problems, trauma: 'espanto', fever }\end{array}$ & 4 & $\mathrm{~N}$ & $\mathrm{R}, \mathrm{F}$ & $\mathrm{V}$ \\
\hline Tagetes erecta $\mathrm{L}$. & $\begin{array}{l}\text { Flor de Muerte, } \\
\text { Tu'tz' }\end{array}$ & $\begin{array}{l}\text { Sacred, parasites, antibiotic, leukemia, colic, tetanus, } \\
\text { stimulating immune system, wound healing, analgesic }\end{array}$ & 4 & Asthma, tuberculosis, pneumonia, headache & 3 & $\mathrm{~N}$ & $\mathrm{R}$ & $\mathrm{V}$ \\
\hline $\begin{array}{l}\text { Tanacetum parthenium } \\
\text { (L.) Sch.Bip. }\end{array}$ & Altamisa & $\begin{array}{l}\text { Blood purification', analgesic, 'stomach acidity', parasites, } \\
\text { lesions, cough, rheumatism, inflammations, facilitating } \\
\text { delivery, menstruation, sacred, skin: 'granos' }\end{array}$ & 4 & & 0 & I & $\mathrm{C}, \mathrm{R}$ & $\mathrm{V}$ \\
\hline Piper tuerckheimii C.DC. & Kuxtin Q'ehen & & 0 & $\begin{array}{l}\text { Dengue, fever, epilepsy, bad spirits causing } \\
\text { constipation and urinary issues, } \\
\text { menstruation, wound healing, antibiotic }\end{array}$ & 4 & - & $\mathrm{R}, \mathrm{F}$ & $\mathrm{V}$ \\
\hline Piper peltatum L. & Yut'it' & & 0 & $\begin{array}{l}\text { Uterine pain, allergies, vaginal hemorrhage, } \\
\text { diarrhea, skin issues 'granos', uterus, body } \\
\text { pain, bad spirits causing constipation and } \\
\text { urinary issues }\end{array}$ & 5 & - & $\mathrm{C}, \mathrm{R}, \mathrm{F}$ & $\mathrm{V}$ \\
\hline Pimpinella anisum L. & Anis & $\begin{array}{l}\text { Alcoholism, stimulates delivery, contractions, antibiotic, } \\
\text { children that cry a lot, arthritis, cramps }\end{array}$ & 3 & & 0 & I & - & $\mathrm{L}$ \\
\hline $\begin{array}{l}\text { Neurolaena lobata (L.) } \\
\text { R.Br. ex Cass. }\end{array}$ & $\begin{array}{l}\text { Tres Puntas, K'a' } \\
\text { Mank' }\end{array}$ & & 0 & $\begin{array}{l}\text { Gastritis, malaria, bone pain, cancer, fever, } \\
\text { itching }\end{array}$ & 4 & $\mathrm{~N}$ & $\mathrm{R}, \mathrm{F}$ & $\mathrm{V}$ \\
\hline Momordica charantia L. & $\begin{array}{l}\text { Sandía de Ratón, } \\
\text { Jaime, } \\
\text { Sandiy'cho }\end{array}$ & & 0 & $\begin{array}{l}\text { Gastritis, diabetes, dengue, malaria, } \\
\text { rheumatism }\end{array}$ & 4 & I & $\mathrm{C}, \mathrm{R}$ & $\mathrm{V}$ \\
\hline
\end{tabular}


Table 4: Medical use classification in the two linguistic groups. Categories are defined as modifications of the WHO's International Statistical Classification of Diseases and Related Health Problems (ICD-10; World Health Organization 2015) . Original chapters annotated behind category name. \# UR's [\%]: Relative share of total use reports by linguistic group. ( $\mathrm{N}_{\mathrm{UR}} \mathrm{N}_{\mathrm{T}}$ ), $\mathrm{F}_{\mathrm{ic}}$ : Absolute number of UR's, number of genera, and (in bold) consensus factor by category.

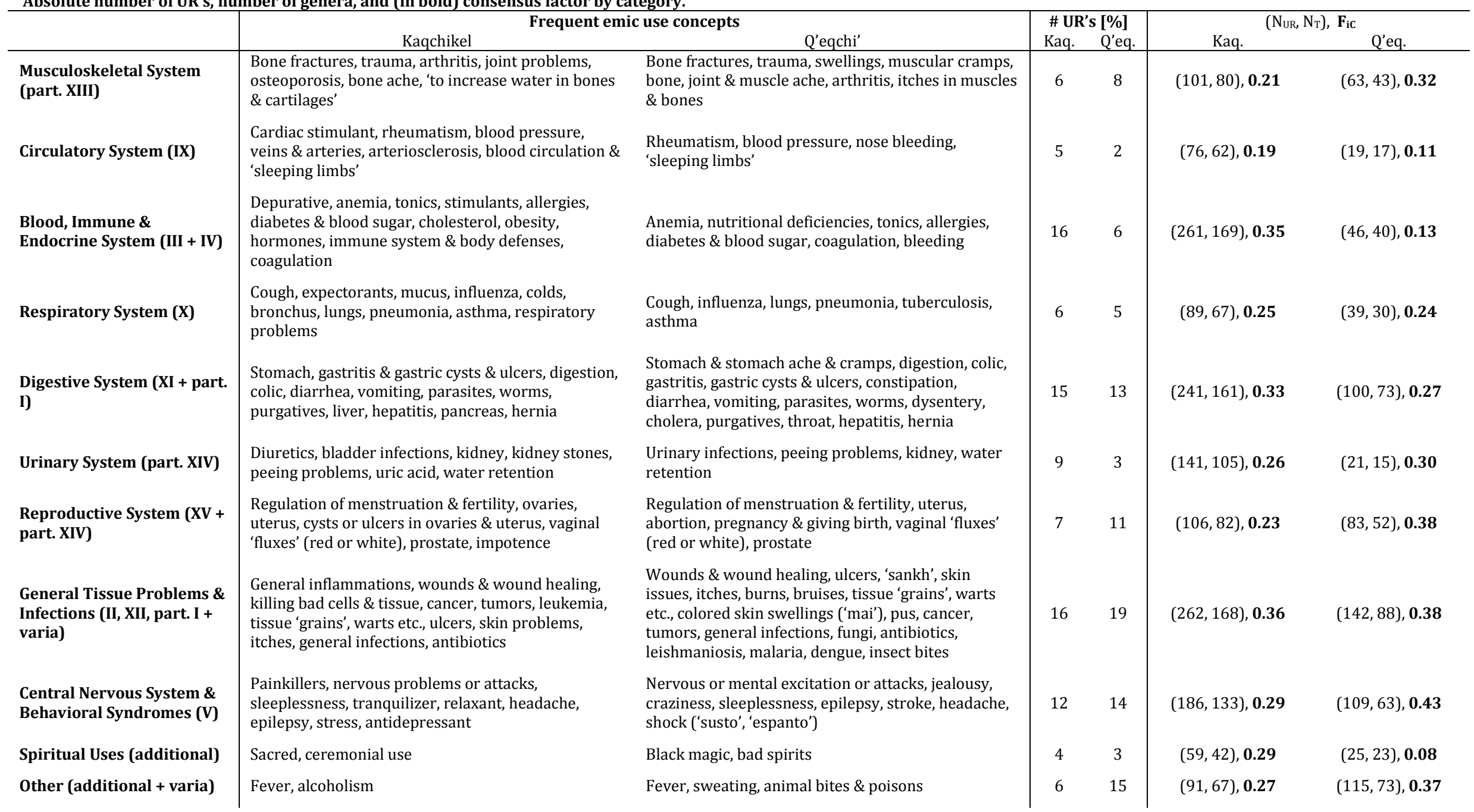


Table 5: Full list of species with four or more Use Reports in one and the same class, and its uses in that class.

\begin{tabular}{|c|c|}
\hline \multicolumn{2}{|c|}{ Musculoskeletal System } \\
\hline Bursera simaruba (L.) Sarg. & 'Golpes' - lesions due to hits, pain in body \& bones \\
\hline \multicolumn{2}{|r|}{ Circulatory System } \\
\hline Cymbopogon citratus (DC.) Stapf & Problems of blood pressure, improve circulation \\
\hline \multicolumn{2}{|c|}{ Blood, Immune \& Endocrine System } \\
\hline Solanum nigrescens M. Martens \& Galeotti & 'Blood purification \& weakness', diabetes, cholesterol, anemia \\
\hline \multicolumn{2}{|r|}{ Respiratory System } \\
\hline Eucalyptus cinerea F.Muell. ex Benth. & Pulmonary \& bronchial problems, influenza, cough, asthma \\
\hline \multicolumn{2}{|r|}{ Digestive System } \\
\hline Ricinus communis L. & Purgative, parasites, amoebas \\
\hline Dysphania ambrosioides (L.) Mosyakin \& Clemants & Stomach ache, parasites, purgative, diarrhea, vomiting \\
\hline Carica papaya $\mathrm{L}$ & Digestive, stomach infections, parasites, purgative \\
\hline \multicolumn{2}{|r|}{ Urinary System } \\
\hline Arthrostemma ciliatum Pav. ex D. Don & Pain during urination, urinary infections \\
\hline \multicolumn{2}{|c|}{$\begin{array}{l}\text { Reproductive System } \\
\text { none }\end{array}$} \\
\hline \multicolumn{2}{|c|}{ General Tissue Problems \& Infections } \\
\hline Aloe vera (L.) Burm.f. & Infections, inflammations, wounds, ulcers, tumors, cysts \\
\hline Blepharidium guatemalense Standl. & Ulcers, 'sankh', leishmaniasis - 'mosca chiclera', antibiotic \\
\hline Hamelia patens Jacq. & $\begin{array}{l}\text { Skin problems: 'granos, ronchas', itching, inflammations, ulcers, } \\
\text { leishmaniosis - 'mosca chiclera', tumors }\end{array}$ \\
\hline Plantago major L. & Infections, inflammations, wounds, ulcers, cysts, cancer \\
\hline Semialarium mexicanum (Miers) Mennega & $\begin{array}{l}\text { Cancer, ulcers, inflammations, infections, fibromas in uterus and } \\
\text { breast, wounds }\end{array}$ \\
\hline Rivina humilis L. & $\begin{array}{l}\text { Tissue problems: 'nacidos, granos, ronchas', itching, cancer, ulcers, } \\
\text { wounds }\end{array}$ \\
\hline Struthantus sp. & $\begin{array}{l}\text { Antibiotic, inflammations, skin problems: 'mai', 'masas', gastritis, } \\
\text { ulcers, cysts, tumors, wounds }\end{array}$ \\
\hline \multicolumn{2}{|c|}{ Central Nervous System \& Behavioral Syndromes } \\
\hline Erythrina berteroana Urb. & Nervous problems, 'epilepsy', pain, sleeplessness \\
\hline Tilia platiphyllus Scop. & Relaxant, cramps, 'epilepsy', nerves, analgesic, sleeplessness \\
\hline Verbena litoralis Kunth & Analgesic, relaxant, 'epilepsy', cramps \\
\hline \multicolumn{2}{|r|}{ Spiritual Uses } \\
\hline Rosmarinus officinalis L. & Sacred, ceremonial, saturations, 'energy of the blood', black magic \\
\hline
\end{tabular}

\subsection{Ethno-pharmacopoeias reflect societal context}

Table 4 provides information on the relative frequency of use for each class (\% of total UR's per region). Use classes differentiate into classes of lower $(\leq 9 \%)$ and higher frequency $(\geq 11 \%)$. The following uses are frequent in both groups: (1) digestive system, (2) central nervous system and behavioral syndromes, and (3) general tissue problems \& infections. Furthermore in the Kaqchikel area (1) the blood, immune \& endocrine system is cited frequently, containing frequent references to blood 'purification' ('depurativo', 'limpiador de la sangre'). In the Q'eqchi' area, (1) the reproductive system and (2) the residual category "other" are frequent. This is due to frequent references to (1) conditions relating to menstruation and vaginal discharges and problems of the uterus (e.g. 'partos', 'matriz', 'flujos vaginales'), and (2) to fever and sweating (e.g. 'calentura', 'fiebre', 'sudor'). Spiritual uses are infrequent in both groups. In addition, in the Q'eqchi' area, the circulatory system and the urinary system are rarely mentioned.

Therefore, some of the most common classes of remedies, for the digestive system, the central nervous system and behavioral disorders, and tissue complaints are shared, while each group has other categories with particular prominence. Notably, the digestive system contains many of the communicable 
diseases traditionally common to societies in developing countries. In contrast, the most prominent difference concerns the categories (1) blood, immune \& endocrine system, and (2) circulatory system. These include the majority of chronic, non-communicable diseases (diseases of affluence) like diabetes, obesity, hormonal problems, allergies, syndromes of the immune system, arteriosclerosis, and problems of blood pressure. UR's for these classes are almost three times as common in the Kaqchikel area as in the Q'eqchi' area (21\% of UR's as compared to 8\%). This reflects the so-called double burden of diseases experienced by many developing countries (Boutayeb 2006), which are unable to control communicable diseases as effectively as developed countries, and yet also have to deal with the non-communicable diseases associated with affluence. This seems more pronounced in the Kaqchikel area, which again coincides with this groups higher and more "developed" standard of living.

\subsection{Ethno-pharmacopoeias reflect sociocultural history}

Table 5 shows a full list of species with four or more UR's within the same use class. However, as the table shows there are very few such examples. This is illustrated more comprehensively in Table 4: the consensus based on the FIC is relatively low in all classes, not a single class exceeds 0.43 . Some clearly defined emic categories like diabetes and blood sugar level were tested as alternatives, but showed similarly low consensus. Among almost all classes, there is a very clear relationship between class size and FIC (Figure 2) as known from other studies (Heinrich et al. 1998). Since the majority of UR's refer to various diseases in different classes, increasing sample size by merging categories linearly increases $\mathrm{N}_{U R}$, whereas $\mathrm{N}_{\mathrm{t}}$ increases according to limited growth. Therefore, the ones with high FIC despite of small class size are most consensual. In the Kaqchikel area, these are spiritual uses. In the Q'eqchi' area, it is the urinary system. Overall however, a consensus of identifying certain taxa with particular use classes does not seem to exist even at genus level. This adds to the lack of repeated UR's and can be explained in different ways.

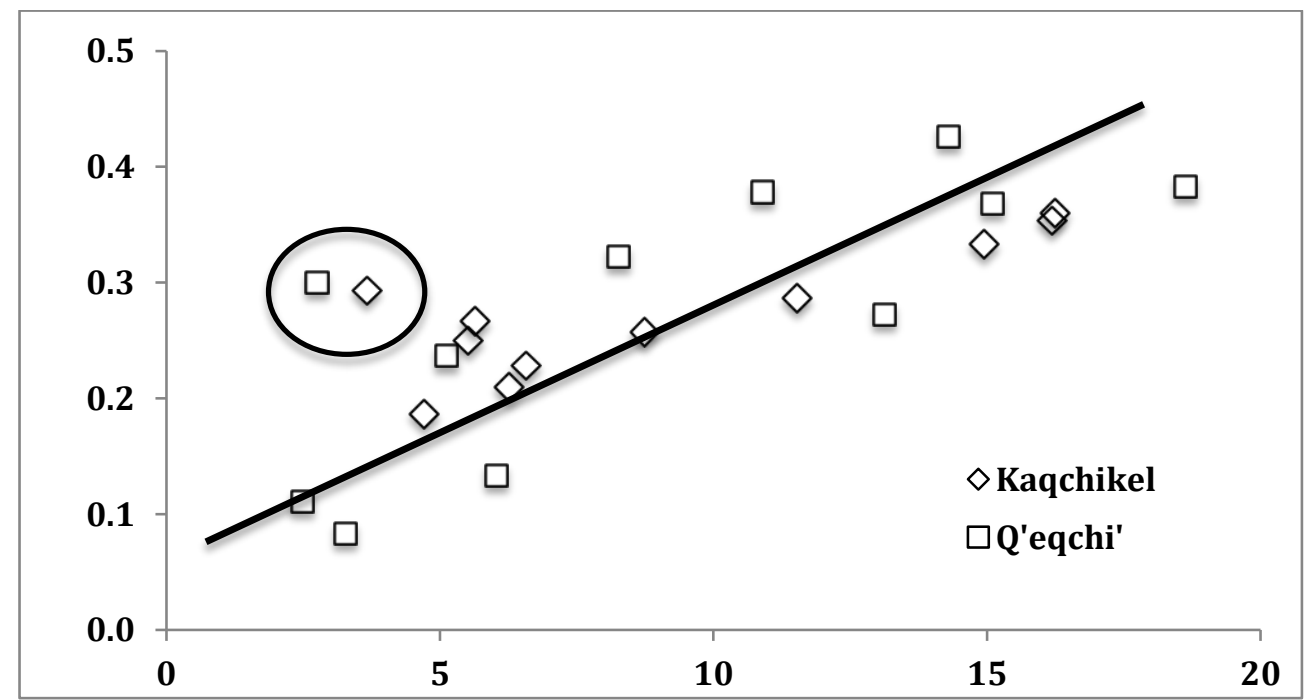

Figure 2: Consensus factors ( $F_{i c}, y$-axis) as a function of relative share of Use Reports ( $x$-axis). Added: a tentative linear relationship between $F_{\text {ic }}$ and class size, and categories with relatively high consensus despite of low class size (marked with a circle). 
On the one hand, many of the species and UR's from individual healers earned broad support during the validation workshops, without appearing in other healers' free-listings or collections. This suggests some consensus in terms of emically defined categories, the botanical equivalent of which are complexes of medicinal species (Bye and Linares 2015, Linares and Bye 1987). The genera level as applied in the consensus analysis might simply not be the right analytic approach. Also, finding consensus might require scaling-up of the effort due to having accessed random portions of each healer's total knowledge.

On the other hand, knowledge in both groups is likely to be fragmented. This is in part due to the healers living quite far from each other and in slightly different biomes, which introduces a level of natural and cultural variation mostly unknown in ethnobotanical research focusing on single communities (as e.g. in Heinrich et al. 1998). This casts doubt on the use of the FIC in a regional setting covering an ethic group. During the colonial period, the Catholic Church burnt codified Mayan knowledge. At least in the Kaqchikel area, exchange between the reductions was severely limited, and during the civil war Mayan healers and priests (including many of the healers in our study) were targeted and persecuted for allegedly being communist guerilla leaders. As a result, many networks of communication and exchange were destroyed or forced into hidden societal niches. This is exemplified by the transmission pathways of knowledge, which tend to be a secretive teacher-student relationship. However, in recent years group formats of learning that would allow open exchange have been introduced in the Q'eqchi' area.

\subsection{Understanding medical change}

Field observations have shown that some reported species are introduced from other regions, such as rosemary (Rosmarinus officinalis L.): a species from the Mediterranean region that was frequently reported in the Kaqchikel area and collected in open lands. Its history of cultural adoption in Mesoamerica has been discussed in a previous publication (Heinrich et al. 2006). Table 3 presents more examples. Overall, the phytogeographic origin of 289 of the 530 identified species could be established. Of those, 212 are native to Guatemala, Mesoamerica or Central America, and 77 are introduced from other regions. In the Q'eqchi' area, the phytogeographic origin of 132 (out of 284) species could be established, out of which only 11 are introduced. Importantly, hardly any of the species listed in the Q'eqchi' area are marketed or processed remedies. In the Kaqchikel area, the origin of 176 (out of 324) species could be established, out of which 69 are introduced, and many are rarely found naturalized. Thus, in contrast to the Q'eqchi' area, the medicine in the Kaqchikel area is strongly influenced by knowledge and use of non-native plants.

This can be interpreted as resulting from two different (not mutually exclusive) processes: (1) Differences in numbers or frequency of occurrence of introduced species, or (2) different cultural experiences shaping the adoption of introduced species and their medical uses. Some indication supports the first hypothesis, such as the limited impact the colonial and independent governments had on Petén ecosystems until the 1970's. However, due to the lack of biogeographical data on introduced species, this remains up for further research.

In contrast, the history of the two groups provides convincing arguments to support the hypothesis of divergent sociocultural opportunities or dispositions 
for contact with new and introduced knowledge. The Kaqchikeles' language skills and education enable them to use books and other materials to extend their knowledge beyond that transmitted to them by personal Mayan teachers. Their location has historically brought them into much closer contact with the Spanish clerics who cultivated European medicinal plants in convent gardens. Their urban lifestyles mean they now have little access to many native species, while marketed and introduced remedies are easily accessible. Fieldwork insight testifies they do make extensive use of these options. At the same time, the Q'eqch'i were relatively isolated throughout the colonial era. Until the 1970's (when the interviewed healers received the majority of their knowledge and before the advent of modern infrastructure to remote lowland regions) they were living in regions bountiful of primary forest, while access to marketed goods was limited. Until today, language and literacy barriers prevent them from exchanging easily with non-Maya counterparts or books.

\section{Conclusion}

This study is one of very few major collaborative ethnobotanical investigations anywhere in the world and certainly one of the very first in Central America and México. For the first time, the objectives, research design and sampling strategy were developed jointly between informants and investigators, and some of the project steering and fieldwork were conducted together. Furthermore, the research question and the methodology aimed both at documenting and strengthening medical practice in the two areas. It, therefore, is an example of north-south cooperation using TD. Despite practical limitations in the difficult context of Guatemalan society, advantages include the facilitation of contacts and networks, legitimacy of the research, building of trust and capacity, and empowerment. It thus enables scientifically rigorous and societally relevant fieldwork and provides evidence for a TD methodology being an important enabler in facilitating the collection of comparative data in a geographical and cultural space, the breadth of which has rarely been reached in individual projects.

As the first major investigation of medicinal plants in of Guatemala, it greatly extends knowledge of the ethnic pharmacopoeias. Contrary to many studies it uses a comparative approach to investigate the medicinal plant use of two indigenous groups. Although not complete, it represents the knowledge of the group's most reputed phyto-therapeutic healers and, it is a representative selection of the Guatemalan medicinal flora (with specific, well-defined exceptions to be complemented in future investigations). Whilst very few ethnobotanical studies have so far critically reflected upon the strategies of informant selection as part of the research process, our TD approach has fostered the mutual recognition of such a selection by the Councils of Elders and the researchers, and this paper is novel in highlighting this step as crucial for the representativeness of results.

The application of the ICD-10 in structuring the knowledge was a pragmatic approach to providing a robust general overview. However, it also demonstrates the lack of any one-fits-all solution for cultural comparisons. The starting point for further analyses would be the development of a classification system tailored to the pertinent research objectives. 
The two ethno-pharmacopoeias are remarkably diverse. Whilst more detailed studies might reveal greater consensus than we could discern, the differences may be real and reflect historical and biogeographic factors. An additional level of fragmentation or relative reduction of knowledge due to the migratory history of Q'eqchi' healers was not observed. Overcoming that fragmentation for a resystematization of traditional knowledge is one motivation for the Maya councils to support this research, but new approaches are required to assess how coherent Maya phytotherapy really is.

An important motivation for the Maya Councils of Elders to participate in the study was to document their ancient knowledge, and so prevent it from disappearing. However, our results provide evidence that the pharmacopoaeia of the Kaqchikel area has changed considerably in response to external conditions and new medical challenges. This finding demonstrates the adaptive potential of phytotherapy and suggests that, in a rapidly changing world, indigenous pharmacopoeias cannot be equated with 'traditional' medicine. Indeed, it seems more appropriate to classify plant use as operationally adaptive strategies, which are integrated into more stable elements of medical thought and practice, as evidenced in ETH's wider project on Maya medicine (Ivic de Monterroso 2016). In this sense, the results are an empirical confirmation of postulated hierarchies of cultural significance (Rappaport 1979). Overall, this study reinforces the perspective that it would be better to use the term 'local' phytotherapies, and to reserve the term 'traditional' for the study of those indigenous pharmacopoeias where the methodology allows a clear delineation of ancient knowledge.

\section{Acknowledgements}

Assembling the database presented in this paper has been a long process with many people involved. I would in particular like to thank the healers and council members for their trust, commitment, invested time, assistance with coordination and for sharing their knowledge. I hope the documented knowledge will contribute to one of their main interests at stake: strengthening their culture in times of change.

My colleague Dr. Mónica Berger-Gonzalez was important in many ways, having assembled the initial project platform and being available for discussions and reflections are just the most important ones. Hugo Ax Che provided important contributions in collecting the dataset in the Q'eqchi' area. Other contributions in fieldwork and administration were made by Dr. Caroline Weckerle, Dr. Mónica Stein, Dr. Sara Barrios, María Alvarez Ruano, Daniela Ochaíta Santizo, Samuel Secaira, Paodillo Hernández, Gregorio Hernández, Ana-Isa Enríquez and Isabel Alvéstegui-Müller.

Furthermore, I collectively thank all persons and families who invited me to their homes, shared with me their life, introduced me to their country, their culture, their joy and their challenges, and made possible a two-year experience of life as a digital nomad.

Last but not least, Dr. rer. nat. habil. Stefan Wanke, José Manuel Ramírez Amezcua, Prof. Dr. Susanne Renner and Dr. Rafael Lira Saade have revised identifications in difficult plant families, and Alice Hertzog revised the manuscript for editing and writing style. ETH Zurich provided the funding. 


\section{References}

Adams, RN. (1997): El Surgimiento de la Identidad Maya. In Luján Muñoz J., Contreras JD. (Eds.): Historia General de Guatemala Vol. VI: Época Contemporánea: De 1945 a La Actualidad, pp. 317-46. Guatemala City: Asociación de Amigos del País. Fundación para la Cultura y el Desarrollo.

Aguilar EC. (1994): Los Cakchiqueles. In Luján Muñoz J., Popenoe de Hatch M. (Eds.): Historia General de Guatemala Vol. II: Dominación Española: Desde La Conquista Hasta 1700, pp. 533-52. Guatemala City: Asociación de Amigos del País. Fundación para la Cultura y el Desarrollo.

Arnstein SR. (1969): A Ladder of Citizen Participation. J. Am. Inst. Plan. 35: 21624.

Balick MJ., Arvigo R. (2015): Messages from the Gods, a Guide to the Useful Plants of Belize. New York: Oxford University Press.

Berger-Gonzalez M. (2015): Towards Relating Maya and Contemporary Conceptions of Cancer: A Transdisciplinary Process to Foster Intercultural Scientific Exchange. ETH Zurich. http://ecollection.library.ethz.ch/eserv/eth:47903/eth-47903-01.pdf $\quad$ (accessed: March 13, 2016).

Berger-Gonzalez M., Stauffacher M., Zinsstag J., Edwards P., Krütli P. (2016): Intercultural Research on Cancer Healing Systems between Biomedicine and the Maya of Guatemala: A Transdisciplinary Approach to Induce Reciprocal Reflexivity in a Multi-Epistemological Setting. J. Qualitative Health Research 26 (1): 77-91.

Berlin B., Berlin EA. (2004): Community Autonomy and the Maya ICBG Project in Chiapas, Mexico: How a Bioprospectig Project That Should Have Succeeded Failed. Human Organization 63 (4): 472-86.

Boutayeb A. (2006): The Double Burden of Communicable and NonCommunicable Diseases in Developing Countries. Transactions of the Royal Society of Tropical Medicine and Hygiene 100: 191-99.

Bye R., Linares E. (2015): Perspectives on Ethnopharmacology in Mexico. In Heinrich M., Jäger AK. (Eds.): Ethnopharmacology, pp. 393-404. ULLA Series in Pharmaceutical Sciences. Wiley Blackwell.

Bye R., Linares E., Estrada E. (1995): Biological Diversity of Medicinal Plants in Mexico. In Arnason JT., Mata R., Romeo JT. (Eds.): Phytochemistry of Medicinal Plants, pp. 29:65-82. Recent Advances in Phytochemistry. New York: Springer Science \& Business Media, LLC.

Cáceres A. (2009): Vademecum Nacional de Plantas Medicinales de Guatemala. Guatemala City: Editorial Universitaria USAC.

Cáceres A., Menéndez H., Méndez E., Cohobón E., Samayoa BE., Jauregui E., Peralta E., Carrillo G. (1995): Antigonorrhoeal Activity of Plants Used in Guatemala for the Treatment of Sexually Transmitted Diseases. J. Ethnopharmacology 48 (2): 85-88.

Carcache HC. (1994): Organización Política de Los Indios. In Luján Muñoz J., Aguilar EC. (Eds.): Historia General de Guatemala Vol. II: Dominación Española: Desde La Conquista Hasta 1700, pp. 143-54. Guatemala City: Asociación de Amigos del País. Fundación para la Cultura y el Desarrollo. 
Castañeda C. (2008): Guatemala y su Biodiversidad: Un Enfoque Histórico, Cultural, Biológico y Económico. Technical Report 67. Guatemala City: Consejo Nacional de Areas Protegidas. http://www.chmguatemala.gob.gt/informacion/libro-biodiversidad-deguatemala/Capitulo\%204.pdf (accessed: July 17, 2015).

CIA (2015): CIA World Factbook. https://www.cia.gov/library/publications/theworld-factbook/geos/gt.html (accessed: July 17, 2015).

CONAP (1999): Conociendo el Sistema Guatemalteco de áreas Protegidas Estrategia Nacional para la Conservación y Uso Sostenible de la Biodiversidad. Guatemala City: Consejo Nacional de Areas Protegidas.

Consejo Mayor de Médicos Maya'ob' por Nacimiento (2016): Raxnaq'il Nuk'aslemal: Medicina Maya'ob' en Guatemala. Guatemala City: Editorial Cholsamaj.

Convention on biological diversity (2015): The Nagoya Protocol on Access and Benefit-Sharing. https://www.cbd.int/abs (accessed: July 17, 2015).

Didier B. (1994): Los Lacandones e Itzaes. In Luján Muñoz J., Aguilar EC. (Eds.): Historia General de Guatemala Vol. II: Dominación Española: Desde La Conquista Hasta 1700, pp. 645-62. Guatemala City: Asociación de Amigos del País. Fundación para la Cultura y el Desarrollo.

Ethnologue (2015): Ethnologue: Languages of the World. https://www.ethnologue.com/country/GT (accessed: July 17, 2015).

Etkin NL., Elisabetsky E. (2005): Seeking a Transdisciplinary and Culturally Germane Science: The Future of Ethnopharmacology. J. Ethnopharmacology 100: 23-26.

Gridling M., Stark N., Madlener S., Lackner A., Popescu R., Benedek B., Diaz R., Tut FM., Nha V., Thanh P. (2009): In Vitro Anti-Cancer Activity of Two EthnoPharmacological Healing Plants from Guatemala Pluchea Odorata and Phlebodium Decumanum. Int. J. Oncology 34 (4): 1117-28.

Häberli R., Grossenbacher-Mansuy W. (1998): Transdisziplinarität zwischen Förderung und Überforderung. Erkenntnisse aus dem SPP Umwelt. GAIA 7 (3): 196-213.

Heinrich M., Ankli A., Frei B., Weimann C., Sticher O. (1998): Medicinal Plants in Mexico: Healers' Consensus and Cultural Importance. Soc. Sc. Med. 47 (11): 1859-71.

Heinrich M., Edwards S., Moerman DE., Leonti M. (2009): Ethnopharmacological Field Studies: A Critical Assessment of their Conceptual Basis and Methods. J. Ethnopharmacology 124: 1-17.

Heinrich M., Kufer J., Leonti M., Pardo-de-Santayana M. (2006): Ethnobotany and ethnopharmacology-Interdisciplinary Links with the Historical Sciences. J. Ethnopharmacology 107: 157-60.

Herrera G. (1997): Idiomas Indígenas: Situación Actual y Futuro. In Luján Muñoz J., Contreras JD. (Eds.): Historia General de Guatemala Vol. VI: Época Contemporánea: De 1945 a La Actualidad, pp. 355-66. Guatemala City: Asociación de Amigos del País. Fundación para la Cultura y el Desarrollo.

Hitziger M., Ochaíta-Santizo DM., Berger-Gonzalez M. (2016): Q'ayis Ajq'om Chin Utz Qak'aslemal: Fitoterapia Maya en Guatemala. In Consejo Maya de Guias 
Espirituales y Medicos de Nacimiento (Ed.): Raxnaq'il Nuk'aslemal: Medicina Maya'ob' en Guatemala. Guatemala City: Editorial Cholsamaj.

Instituto Nacional de Estadística (2014): de Guatemala 2012. http://www.ine.gob.gt/sistema/uploads/2014/02/26/5eTCcFlHErnaNVeUm m3iabXHaKgXtw0C.pdf (accessed: July 17, 2015).

Ivic de Monterroso M. (2016): Esta Enfermedad ¿Tiene Un Dueño? La Medicina entre los Mayas del Posclásico. In Consejo Maya de Guias Espirituales y Medicos de Nacimiento (Ed.): Raxnaq'il Nuk'aslemal: Medicina Maya'ob' en Guatemala. Guatemala City: Editorial Cholsamaj.

Jones CL. (1940): Guatemala, Past and Present. Minneapolis: University of Minneapolis Press.

Kahn HE. (2006): Seeing and Being Seen: The Q'eqchi' Maya of Livingston, Guatemala and beyond. Austin: University of Texas Press.

Kirchhoff P. (1943): Mesoamérica, sus Límites Geográficos, Composición étnica y Carácteres Culturales. Acta Americana 1: 92-107.

Krütli P., Stauffacher M., Flüeler M., Scholz RW. (2010): Functional-Dynamic Public Participation in Technological Decision-Making: Site Selection Processes of Nuclear Waste Repositories. J. Risk Research 13 (7): 861-75.

Kufer J., Förther H., Pöll E., Heinrich M. (2005): Historical and Modern Medicinal Plant Uses: The Example of the Ch'orti' Maya and Ladinos in Eastern Guatemala. J. Pharmacy and Pharmacology 57: 1127-52.

Leonti M., Vibrans H., Sticher O., Heinrich M. (2001): Ethnopharmacology of the Popoluca, Mexico: An Evaluation. J. Pharmacy and Pharmacology 53: 1653-69.

Linares E., Bye RA. (1987): A Study of four Medicinal Plant Complexes of Mexico and Adjacent United States. J. Ethnopharmacology 19: 153-83.

Lutz CH. (1994): Evolución Demográfica de La Población No Indígena. In Luján Muñoz J., Aguilar EC. (Eds.): Historia General de Guatemala Vol. II: Dominación Española: Desde La Conquista Hasta 1700, pp. 249-58. Guatemala City: Asociación de Amigos del País. Fundación para la Cultura y el Desarrollo.

Madlener S., Svacinová J., Kitner M., Kopecky J., Eytner R., Lackner A., Nha V., Frisch R., Grusch M., De Martin R. (2009): In Vitro Anti-Inflammatory and Anticancer Activities of Extracts of Acalypha Alopecuroidea (Euphorbiaceae). Int. J. Oncology 35 (4): 881-91.

Martin JF., Roy ED., Diemont SAW., Ferguson BG. (2010): Traditional Ecological Knowledge (TEK): Ideas, Inspiration, and Designs for Ecological Engineering. Ecological Engineering 36: 839-49.

McCreery D. (1995a): Agricultura. In Luján Muñoz J., Herrarte A. (Eds.): Historia General de Guatemala Vol. IV: Desde La República Federal Hasta 1898, pp. 481502. Guatemala City: Asociación de Amigos del País. Fundación para la Cultura y el Desarrollo.

_-_ (1995b): El Café y sus Efectos en la Sociedad Indígena. In Luján Muñoz J., Herrarte A. (Eds.): Historia General de Guatemala Vol. IV: Desde La República Federal Hasta 1898, pp. 503-34. Guatemala City: Asociación de Amigos del País. Fundación para la Cultura y el Desarrollo. 
Michel J, Duarte RE., Bolton JL., Huang Y., Cáceres A., Veliz M., Soejarto DD., Mahady GB. (2007): Medical Potential of Plants Used by the Q'eqchi Maya of Livingston, Guatemala for the Treatment of Women's Health Complaints. J. Ethnopharmacology 114: 92-101.

Missouri Botanical Garden (2015): Flora Mesoamericana. http://www.tropicos.org/ProjectAdvSearch.aspx?projectid=3\&langid=66 (accessed: Sep. 22, 2015).

Myers N., Mittermeier RA., Mittermeier CG., da Fonseca GAB., Kent J. (2000): Biodiversity Hotspots for Conservation Priorities. Nature 403: 853-58.

Nesheim I., Dhillion SS., Stølen KA. (2006): What Happens to Traditional Knowledge and Use of Natural Resources When People Migrate? Human Ecology 34 (1): 99-131.

Pesek T., Abramiuk M., Fini N., Rojas MO., Collins S., Cal V., Sanchez P., Poveda L., Arnason J. (2010): Q'eqchi' Maya Healers' Traditional Knowledge in Prioritizing Conservation of Medicinal Plants: Culturally Relative Conservation in Sustaining Traditional Holistic Health Promotion. Biodiversity Conservation 19: 1-20.

Pohl C., Hirsch Hadorn G. (2007): Principles for Designing Transdisciplinary Research. Proposed by the Swiss Academies of Arts and Sciences. Munich: Oekom Verlag.

Pohl C., Rist S., Zimmermann A., Fry P., Gurung GS., Schneider F., Speranza CI. (2010): Researchers' Roles in Knowledge Co-Production: Experience from Sustainability Research in Kenya, Switzerland, Bolivia and Nepal. Science and Public Policy 37 (4): 267-81.

Pöll E., Mejía C., Szejner M. (1995): Etnobotánica Garífuna: Livingston, Izabal, Guatemala. Guatemala City: Universidad del Valle de Guatemala.

Rappaport R. (1979): Ecology, Meaning and Religion. Richmond: North Atlantic Books.

Richards M., Richards J. (1994): Lenguas Indígenas y Procesos Lingüísticos. In Luján Muñoz J., Aguilar EC. (Eds.): Historia General de Guatemala Vol. II: Dominación Española: Desde La Conquista Hasta 1700, pp. 345-60. Guatemala City: Asociación de Amigos del País. Fundación para la Cultura y el Desarrollo.

Riera RP. (1997): Infraestructura, Comercio, y Servicios Públicos. In Luján Muñoz J., Contreras JD. (Eds.): Historia General de Guatemala Vol. VI: Época Contemporánea: De 1945 a La Actualidad, pp. 431-50. Guatemala City: Asociación de Amigos del País. Fundación para la Cultura y el Desarrollo.

Roque JM. (1941): Flora Medicoguatemalteca: Apuntes Para La Materia Médica de La República de Guatemala. Guatemala City.

Saint-Lu A. (1994): La Verapaz. In Luján Muñoz J., Aguilar EC. (Eds.): Historia General de Guatemala Vol. II: Dominación Española: Desde La Conquista Hasta 1700, pp. 627-40. Guatemala City: Asociación de Amigos del País. Fundación para la Cultura y el Desarrollo.

Schwartz NB. (1990): Forest Society: A Social History of Peten, Guatemala. Pennsylvania: University of Pennsylvania Press. 
Staub PO., Geck MS., Weckerle CS., Casu L., Leonti M. (2015): Classifying Diseases and Remedies in Ethnomedicine and Ethnopharmacology. J. Ethnopharmacology 174: 514-19.

Stauffacher M., Flüeler T., Krütli P., Scholz RW. (2008): Analytic and Dynamic Approach to Collaboration: A Transdisciplinary Sase Study on Sustainable Landscape Development in a Swiss Prealpine Region. Systemic Practice and Action Research 21 (6): 409-22.

The Plant List (2013): The Plant List, Version 1.1. www.theplantlist.org (accessed: July 15, 2016).

Trotter R., Logan M. (1986): Informant Consensus: A New Approach for Identifying Potentially Effective Medicinal Plants. In Etkin NL. (Ed.): Plants in Indigenous Medicine and Diet: Biobehavioural Approaches. Bedford Hills, New York: Redgrave.

Villar-Anleu (1998): La Flora Silvestre de Guatemala. Guatemala City: USAC.

World Health Organization (2015): International Statistical Classification of Diseases and Related Health Problems 10th Revision. http://apps.who.int/classifications/icd10/browse/2015/en (accessed: Feb. 3, 2016).

\section{Table 6}

This Table presents a full list of identified use reports. Botanical nomenclature is validated with The Plant List (The Plant List 2013). Voucher numbers are given in the column 'source'. If identified by vouchers of other healers during validation workshops this is indicated by (VW). If identified from literature this is indicated as (L). Vouchers that were not given a number by the Herbarium are indicated as SN. Phytogeographic origin (0): $\mathrm{N}=$ native, $\mathrm{I}$ = introduced (according to Cáceres 2009, Missouri Botanical Garden 2015). Linguistic group (G): Q'eqchi' (Q), Kaqchikel (K). Use classification derived from the ICD-10 (World Health Organization 2015): M = Musculoskeletal System, C = Circulatory System, B = Blood, Immune \& Endocrine System, P = Respiratory System, D = Digestive System, U = Urinary System, R = Reproductive System, $T=$ Tissue Problems \& Infections, B = Central Nervous System and Behavioral Syndromes, $S=$ Spiritual-Energetic Uses, $0=0$ ther. Translated use concepts are tentative and only for illustration of the range of reported applications. They are neither aiming for complete representation of source information, nor are the terms medically or linguistically corrobated. 